\title{
The Aerospace "Networked" Business Model: Evidences and Suggestions
}

\author{
Angelo Corallo, Fabrizio Errico, Mariangela Lazoi* \\ Department of Innovation Engineering, University of Salento, Lecce, 73100, Italy \\ *Corresponding Author: mariangela.lazoi@unisalento.it
}

Copyright $@ 2014$ Horizon Research Publishing All rights reserved.

\begin{abstract}
The aerospace industry is characterized by intensive collaborations among firms that work for the realization of complex aerospace products that require high risks and costs. Collaboration and risk sharing are needed at each supply chain level. For companies working in networks, in this period of market changes and crisis, it is needed to think and re-think about a networked business model highlighting the relevance of each collaborating actor in the value generation for new products. The paper aims to explore the business model features of companies working in aerospace networks and to highlight improvements actions. Evidences are collected through a survey and a case study. The research results suggest two new elements for business model frameworks: the value exchange strategy and the value enablers both necessary for an extended collaboration among all nodes of a business network. The introduction of these two elements is discussed and justified in the paper.
\end{abstract}

Keywords Business Model, Network, New Product Development, Aerospace Industry

\section{Introduction}

The increasing competitiveness and technological innovation pushes companies to face an uncertain economic environment that makes business decisions complex and difficult. In high-technological sectors, such as Aerospace and Defense industry, decisions about new products realization, requires the design of a wide net of collaborations to share the product's components development and the related risks and costs.

Generally, companies tend to re-design their product development processes integrating customers and suppliers [1 - 4] and developing innovative forms of collaboration such as the extended or the networked enterprises [5]. Consequently, virtual design teams and globally distributed operating sites have to work in a coordinated way and in an highly disciplined, integrated and synchronized value networks.

Since Business Networks [6] become more and more extended and the economic and technological environment more and more complex, the need emerges to define more sophisticated conceptual models suitable to guide the development of new products within network of companies. Aerospace Sector is an interesting field of exploration for network behaviors. In fact, Aerospace products are high-technology intensive and complex and require investments, knowledge and contribution from many types of industry (e.g. plastics and rubber, metal, glass, textile and electronic components one). They are not realized by only one firm but from networks of firms.

Based on the exploration of this sector, the paper wants to propose a business model suitable to support the collaborative new complex product development process within networks of organizations. The aerospace context is explored with a survey and a case study that lead to the suggestion of some improvements actions.

In the next section, theoretical remarks useful to design the research are reported and organized in a conceptual model. The research model and the main results are then described. Furthermore, a discussion section arguments the results' impact on the conceptual model. A final section of conclusion ends the paper.

\section{Theoretical Remarks}

Ulrich and Eppinger [7] have defined the NPD process as "a sequence of phases and activities executed by the company to conceptualize, design and commercialize a product". Many of these activities are intellectual and organizational more than physical or related to the product structure.

In companies working in networks, it is suitable to define the collaborative new product development as the cooperative relationship between firms to innovate and develop new products [8]. A collaborative product development is led by the complexity of technological and product development, by the rapid rate of product obsolescence and need to access rapidly to the markets [9]. Furthermore, firms establish collaborations with other ones to combine missing skills and the complementarities among 
firms play an important role [10]. Multidisciplinary knowledge is, in fact, necessary to generate and develop new products [11]. Innovation is fostered through cooperation within business relationships and business networks to enhance firms' capabilities and skills [12]. Connecting several firms, the networks define paths and flows on which the resource and idea are shared and the research progress is facilitated [10] enabling to develop an innovation process based on cooperative relationships [13].

Considering a "model" as a simplified representation of the reality and transferring this concept to a networked business environment, the outcome is a representation of the main business activities for company working in network.

The purpose of a business model is to represent the fundamental elements and the relationships among the business activities, in a simplified way, in order to capture the nature and characteristics of highly complex real systems [14]. A general definition of Business Model come from Timmers [15]: "A business model is the "architecture" of product, service and information flows, and the potential benefits and sources of revenues for involved (business) actors". Even though this definition has been widely accepted by researchers, the essence of a business model and the concrete utilization of the term are considered quite ambiguous by the most.

The term business model has, in fact, been referred to as a statement [16], a description [17, 18], a representation [19, 20], an architecture [21, 22], a conceptual tool or model [23; $24 ; 25]$, a structural template [26], a method [27], a framework [28], a pattern [29], and a set [30]. Therefore, literature on Business Model (BM) covers a wide and variegated range of contributions, but a complete overview come from Osterwalder [24]: he describe the concept of

Business Model as "the company's logic of earning money; the architecture of the firm and its network of partners for creating, marketing and delivering value and relationship capital, in order to generate profitable and sustainable revenue streams". In another of his study, it is also affirmed that "a business model describes the rationale of how an organization creates, delivers, and captures value" [31].

There was great emphasis in recent years on the strong link on "Business Model" and "Business Network". Both the concepts was widely discussed in literature, but they still don't fit in the theoretical contribution with each other, since a clear representation of a Business Model suitable to describe the network organization of some group of companies is not yet retrievable. Designing a business model framework means describing the main components on which managers have to deal for better satisfy user needs and desires, and for improve performances of the entire network of participants. This kind of framework should not only include components as a loose collection of elements but it also has to clearly identify their interactions [24, 32, 33].

An important attempt to develop a business model framework suitable to be applied to business networks is presented by Conte [34]. He, in fact, outlines the importance for a business model to satisfy specific requirements (i.e. scalable, generalizable, operational, rigorous, complexity aware) in order to represent the essence of the business performed by the network as a whole, and considering the environmental variables as given.

A further step forward came with the concepts of open innovation and open business model; two terms coined by Chesbrough [35], referring to opening up a company's research process to outside parties. Chesbrough [36] argues that organizations can create more value and better exploit their own research by integrating outside knowledge, intellectual property, and products into their innovation process.

Strategic innovation and open innovation call for the concept of co-creative enterprise [37]. A new approach: companies invite customers to participate directly in the design of products and services. The payoffs of the co-creative enterprise are greater productivity and creativity, lower costs and employees' turnover, and new business models and sources of revenue. While traditional process design strives to meet a defined set of customer requirements and focuses on streamlining existing processes, the co-creation approach, in contrast, aims to serve the interests of all stakeholders [38].

\section{Development of the Conceptual Model}

Based on the previous consideration emerging from the literature landscape, a need of a better representation of a Business Model suitable to describe the network organization of some group of companies has emerged.

New product development, especially in high complex field (e.g. Aerospace Sector), is achieved through the partnership of many actors shared among levels of responsibility along the supply chain. This assumption implies a constant and active interaction among actors during all stages of development.

Furthermore, environmental factors (Political, economic, social and technological variables) create a "turbulence" [39, $40]$ that directly or indirectly force companies to rethink their "Modus Operandi", outlining the importance of defining clearly a Business Models that allows to face the rapid market changes, the pressing demands of customers, and the increasing technological innovation. Companies, in order to adapt to new business conditions, need to collaborate for integrating differentiate factors (i.e. product features, company positions in the value network) that allow to get improvement in competencies and knowledge for product development [41].

The aim of the paper is to propose a new Business Model, going through the creation of a techno-organizational framework, able to support companies and to lead new and improved network performance. These companies collaboratively operate for the new product development for generating value from their activities.

Taking into account the various approaches, existing in the current literature, concerning the business model 
definition and the related components, the choice of the study is to be focused on the contribution of Osterwalder [24] for the approach to the Business Model concept, and Conte [34] for his contribution in the re-interpretation of business model with a specific network perspective.

Starting from the work of these authors, a conceptual model has been developed around four units (see Figure 1)

The Offer Unit covers all the aspects related to what a firm provides to its customers (e.g.. products and services, differentiation strategies) [24, 34]; the Position Unit describes the cooperation context in which the firms interact. It defines who are the partners operating within the business network, which is the role of each one. The Financial Unit describes the way firms generate revenues and profits, explaining the money-making logic of a company [24]. The Value Unit defines the way the value is created by the company. It describes the value system configuration [42] and what abilities are necessary to provide the right Offering Proposition and maintain a suitable customer interface.

This model is an elaboration of the contributions of Osterwalder [24] and Conte [34] that are merged and innovated for a business model suitable to guide the work of network of companies in complex sectors.

The context of the proposed analysis is the "collaborative arena" in which the NPD process is executed and "the Business Model becomes the managerial tool through which align the participants" [43], define the critical points and finally, determine the best solutions, not only for the single enterprise but for the whole network.

\section{Research Methods}

The proposed conceptual model, has been used as framework of reference for the empirical analysis that has aimed to explain the features of the model's units in an industrial field answering to the research question: How are characterized the dimensions of Business Model in a network of aerospace companies to develop new products?

The paper wants to follow a pragmatic approach claim focused on to understand the real-world practice [44]. A mixed method approach, based on a survey and a case study, has been applied to have a complete and sound view on networks in aerospace industry. The survey is designed to collect evidences from a network of small and medium enterprises (SME). The case study is instead designed around a large aerospace company and its collaborations.

The linkages between the two methods are in the data results understanding and comparison using a concurrent triangulation strategy [44]. The data have been collected and analyzed in parallel sections and their findings have been integrated in implications for the conceptual model.

\subsection{The Survey}

The survey has been developed to investigate the last levels of the aerospace supply chain composed by SME. They work as parts and tooling suppliers with different level of expertise and knowledge about the aerospace products. They receive orders from the higher level and have to satisfy specific requirements about quality, security and technology. In particular, the set of SMEs working in the aerospace district in Apulia (a south Italy region) has been chosen. This choice is due to the growing phase in which the sector is involved and by its continuous initiatives of innovation undertaken in the last years.

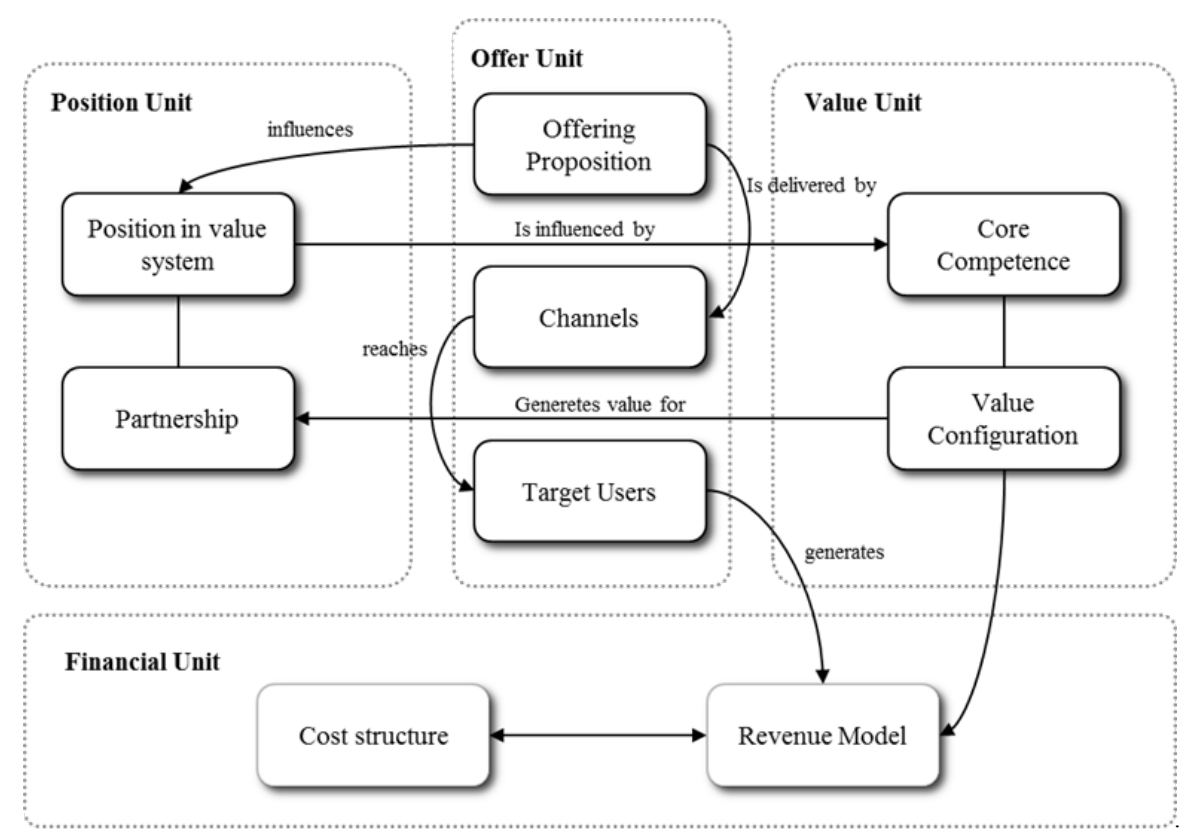

Figure 1. Conceptual Model 
To guide the realization of the survey, a questionnaire has been designed composed by close-end questions [45]. To explore the dynamics and features specified in the conceptual model, the survey questionnaire has been designed around the four conceptual model units. At each unit a set of attributes have been associated (Table 1):

Table 1. The four sections of the survey's questionnaire

\begin{tabular}{|c|c|}
\hline BM Units & Unit Attributes \\
\hline 1. Offer unit & $\begin{array}{ll}\text { - } & \text { Tipology of product/service } \\
\text { provided } \\
\text { - } \\
\text { - } \\
\text { Target customers } \\
\begin{array}{l}\text { Typology of used distribution } \\
\text { channels }\end{array}\end{array}$ \\
\hline 2. Position unit & 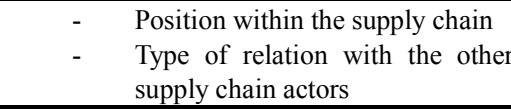 \\
\hline 3. Financial unit & Turnover in the last five year \\
\hline 4. Value unit & $\begin{array}{ll}- & \text { Available ICT } \\
- & \text { Core activities } \\
\text { - } & \text { Employees profile }\end{array}$ \\
\hline
\end{tabular}

The collected data have been object of a descriptive statistical analysis (specially frequencies and cross-tables) [46].

\subsection{The Case Study}

In the case study the focus is, instead, on a sub-assembly supplier that collaborates, with leader firms (major system supplier) and SME. It has to preserve strictly relations with the customers satisfying their technological and product requirements; has to strictly collaborate with companies at the same level of the supply chain and with further external actors (e.g. research centers); and has to work with a wide and intensive net of supply firms at a lower level. The choice of a second level supplier is explained by the important role of intermediate between the higher and lower levels of the supply chain.

This case study has been based on open-ended questions with the aim to better stimulate perspectives, views and opinions sharing among the participants [44].

Three sections exploring the business model units compose the questionnaire: Offer, Location and Value with sets of related attributes (Table 2). They are focalized to explore the context of a large aerospace company and to collect more elements of discussion that can emerge from open-ended questions. The financial unit is missed from the questionnaire but it has been examined looking to the official company' documents.

The case study's questionnaire has been accomplished during face to face interviews with managers and employees using a snowball sample technique [46].

The data analysis and interpretation have followed the Creswell [44] and Bryman and Bell [46] approach for the qualitative procedures. The interviews have been recorded and after transcribed, in order to have an appropriate raw material to code and on which explore the attributes. All the interviews have been read more than one time in order to catch a complete view on the overall organizational situation. The text has been shared in categories representing the main issues related to the attributes. The profile of each interviewee has been also taken in consideration in the reading, coding and analysis.

Table 2. The three sections of the case study's questionnaire

\begin{tabular}{|l|r|}
\hline BM Units & Unit Attributes \\
\hline 1. Offer unit & $\begin{array}{l}\text { Type of product/service provided } \\
-\end{array}$ \\
\hline 2. Position unit & $\begin{array}{l}\text { Type of relation with the other } \\
\text { supply chain actors }\end{array}$ \\
\hline 3. Value unit & $\begin{array}{l}\text { Available ICT } \\
\text { Core activities }\end{array}$ \\
\hline
\end{tabular}

\section{Results}

The evidences collected through the survey and the case study have been organized in the following two sections for guaranteeing the correct comprehension of the two side of the explored context: the SME and the large companies.

\subsection{The Large Aerospace Company}

Twelve interviews have been realized shared with managers and employees working in the Aero-engine and ICT divisions. Three stages of interviews have been followed: two interviews at the first stage, five at the second stage and five at the third stage. All the interviewees have described their flow of activities to realize the product and services provided for their internal or external customers. The external customers are few companies at a higher level of the supply chain working as Original Equipment Manufacturing that manage the realization of a whole engine among several actors worldwide located. The company has more than 5.200 employees and a pay-off for the 2011 of 2 billion of euro.

Analyzing the relevance and quantity of relationships specified during the interviews, it is possible to distinguish among innovative, strategic and operative activities. The main relations, perhaps, in all the types of activities, is with the customers which are, as previous said, few and well defined large companies with which they have agreements for many years. To work with those customers, the company has to respect a wide set of requirements and obtain a positive result to the periodical audience done in its plants. Since its way of working has to be aligned and respect what the customers establish, each activity performed by the company is, thus, influenced by them.

The main relations with the suppliers are, instead, clearly visible in the strategic activities; even if, an appropriate weight is also recognized for the execution of innovative and operative activities. The suppliers are, mainly, SMEs certificated by the company through evaluations of their productive capacity and of the available technologies. The 
productive capacity is very important, delay of a single and small firm, worldwide located, could slow down the production for the whole net of actors impacting negatively on the relationship between the analyzed company and its customers. The available technologies are also important because the availability of the right and most appropriate set of technologies can be a guarantee of product quality and time respect. Therefore, it is required for the SMEs to be technological aligned with the large companies, even if, this could require higher investments that are not supported in any way by the larger companies.

The explored company works also with companies at the same levels and, also, with public or private research centers to collaboratively develop new technologies useful to realize a new product. Innovative activities are also realized to develop new material or to design new production process.

Many and different ICT tools are used by the company and mainly, they are required from their customers as an important pre-requisite to start to work on a given aerospace product. Each organizational activity is realized with the use of ICT tools that support the communication, the design and the management in the new product development process. Many tools are available to support several kinds of data, information and knowledge. In fact, the company is very promising in the digitalization of the whole organizational processes and, further, the tracking of all the documents and activities undertaken with the customers is a wide diffused practice. Problems are visible in the ICT tools used to interface with the suppliers.

\subsection{The SME District}

All the SMEs working for the aerospace sector in Apulia (i.e. 45 firms) have been contacted for participating at the survey. The data collection has been long three months and has been concluded with 29 completed questionnaire (i.e. $64 \%$ answer rate). The interviewed SMEs have been established in high quantity during the period 1990-1999, but are also many the firms younger that are incorporated in the last eight years. They are mainly service and components suppliers (i.e. respectively the $33,33 \%$ and the $25 \%$ of the total), followed by suppliers of semi-finished products and machineries, assemblers and raw materials suppliers. Furthermore, fourteen are the firms with more than one position in the supply chain (i.e. both component and service suppliers.

The collaboration with external actors is widely diffused (i.e. $79.3 \%$ of the firms affirms that collaborate with other ones). It is interesting to observe that the $72.4 \%$ of firms develops internally their innovation and collaborates with external actors, since the innovation process looks widely distributed to involve internal and external capacities. They collaborate mainly with suppliers and universities, following by customers and consulting firms. This explains and designs a network of innovation partners very wide and involving different categories of actors.

Furthermore, asking the type of collaboration, the firms have indicated mainly a customer/supplier relationships, followed by collaborations for technological and production initiatives.

The higher quantity of company has a turnover lower than 5 million of euro, and only two ones have a turnover higher than 10 million euro.

The ICT availability is at a very satisfactory level and ICT solutions are widely used. The $74.1 \%$ of the firms uses ICT systems to support the product design and development (e.g. PLM, PDM, CAD, CAE, CAM). Every firm uses at least a traditional ICT tools such as email, static web-site or office applications. Important results (i.e. respectively $48,1 \%$ and $51,9 \%$ firms) are also visible for the use of ICT systems to support the collaborative working (e.g. Project Management, Workflow Management and Document Management Systems, KM systems) and ICT systems to support the business management (e.g. CRM, SCM, ERP, BI). The results show a wide use of the ICT not only in the core activities but also in the activities to support and control the whole business. This is also confirmed by a general tendency to use the ICT in the whole set of business processes involving both internal and external actors. Furthermore, the percentage of computer connected to Internet on the total number of PC is very high and a wide use of Internet in the product design, product manufacturing, sales management and procurements management processes has been registered.

A high number of firms have developed both innovation of product, process and organizational. The most diffused is the process innovation about new technological production process (i.e. $72,4 \%$ of firms) followed by innovation related to new technological products (i.e. $55,2 \%$ of firms); organizational innovations are also widely diffused and at least one firms on three has introduced an innovation in the managerial techniques, in the work organization and/or in the inter-firm relations.

The teams are almost always multidisciplinary, composed by employees with different competences and skills; this is also explained by the small dimension of the firms and by the involvement of different actors in the innovative efforts.

The total number of employees in the interviewed firms is 1.282. The firms until 10 employees (i.e. the $22 \%$ of the total) have the higher quantity of graduated workers on their total number, often these micro firms are specialized in the service supply and in special way, in the product design and consultancy. For the firm with 10-39 employees (i.e. the $36 \%$ ), they are mainly qualified ones with a lower number of graduated employees. In the firms between 40 and 69 employees (i.e. the $28 \%$ ), mainly, there are under-qualified employees, because increasing the firm size changes its business from service to industrial firm. For the last category (i.e. $>70$ employees; the $14 \%$ ), the employees are equally distributed for each qualification.

\section{Discussion: Impacts on the Business Model}


From the exploration of the empirical context emerges a strong interest towards specific elements considered as essential for the industrial growth and for the business network consolidation and enlargement. These elements are the ICT tools and the strategic relationships. Almost all the analyzed SMEs have adopted adequate ICT systems and continuously are strengthening their technological infrastructure in order to respond at the right time to the external turbulences and consequently to reduce the time to market.

However, technology alone is not enough to guarantee firms chances of survival and for this reason a new network strategy embracing all the actors involved in the NPD process positioned to each levels of the supply chain and guiding towards a whole system innovation is needed.

The results have led to the definition of two new components for the proposed conceptual model (Fig. 2): the "Value Exchange Strategies" and the "Value Enablers". The peculiarity of this new model relies in the capability to leverage exactly on these two new components in order to explore new routes.

The "Value Exchange Strategies" component describes the high-level strategic choices and the conditions to exchange value among different companies which collaborate in the new product development process. Two main areas can be distinguished: the "vertical value exchange strategies" occurring among actors operating at different levels of the productive pyramid and "the horizontal value exchange strategies" among actors working at the same level. The "Value Exchange Strategies" overlaps the "Value Configuration" component in the conceptual model proposal providing a wider and deeper meaning that represents the actual trends and needs of the aerospace companies. The "Value Enablers" component is closely complementary to the previous one. It describes the methodological and technological tools (enablers) that have been taken in consideration to implement the value exchange strategies. Identifying the enablers, describing and accurately associating them with specific "Value Exchange Strategies" is crucial for managers because this provide information on actual business capabilities. Managers needs to specify the most appropriate enablers and to describe and carefully linking them to specific "Value Exchange Strategies" in order to be informed on actual business performance and possibilities of improvements. The "Value Enablers" overlaps the specified "Core Competencies" components providing a more integrating view among the enablers and the network strategies.

The findings can be traduces in a new business model proposition based on two complementary ways to create value (Fig. 3):

- The traditional path (dotted lines) in which the exchange is between product/service and money that is common among all the actors involved of the production process (i.e. major system suppliers, sub-assembly suppliers, part and tooling suppliers).

- The innovative path characterized by two innovative solutions (unbroken lines): the application of a model of "collaborative development" extended to all the actors involved in the new product development process (Value Exchange Strategies) and supported by shared technological solutions (Value Enablers). This new path becomes crucial for SMEs integration into the NPD process.

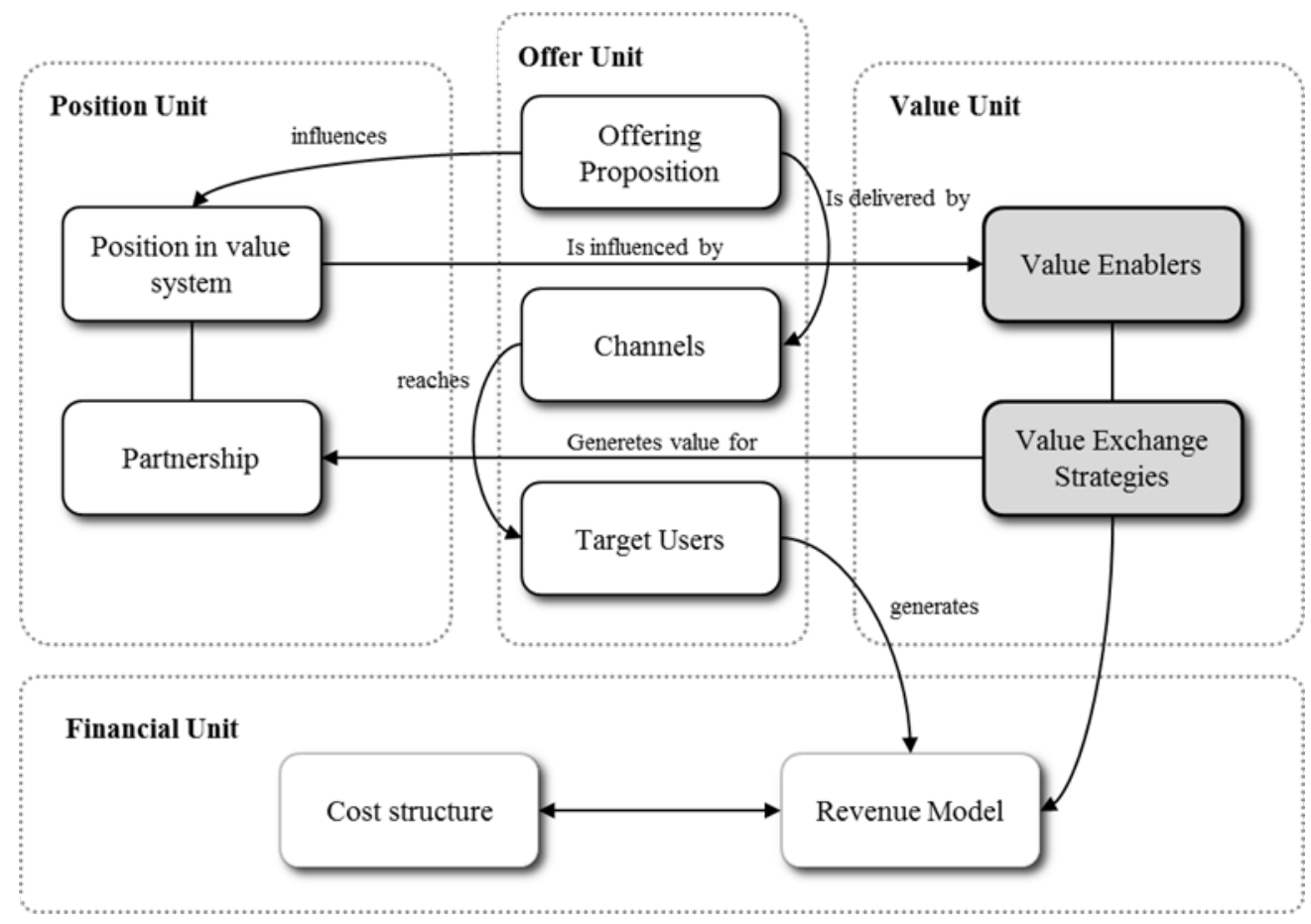

Figure 2. Conceptual MODEL RE-DEFINITION: A Networked business Model 


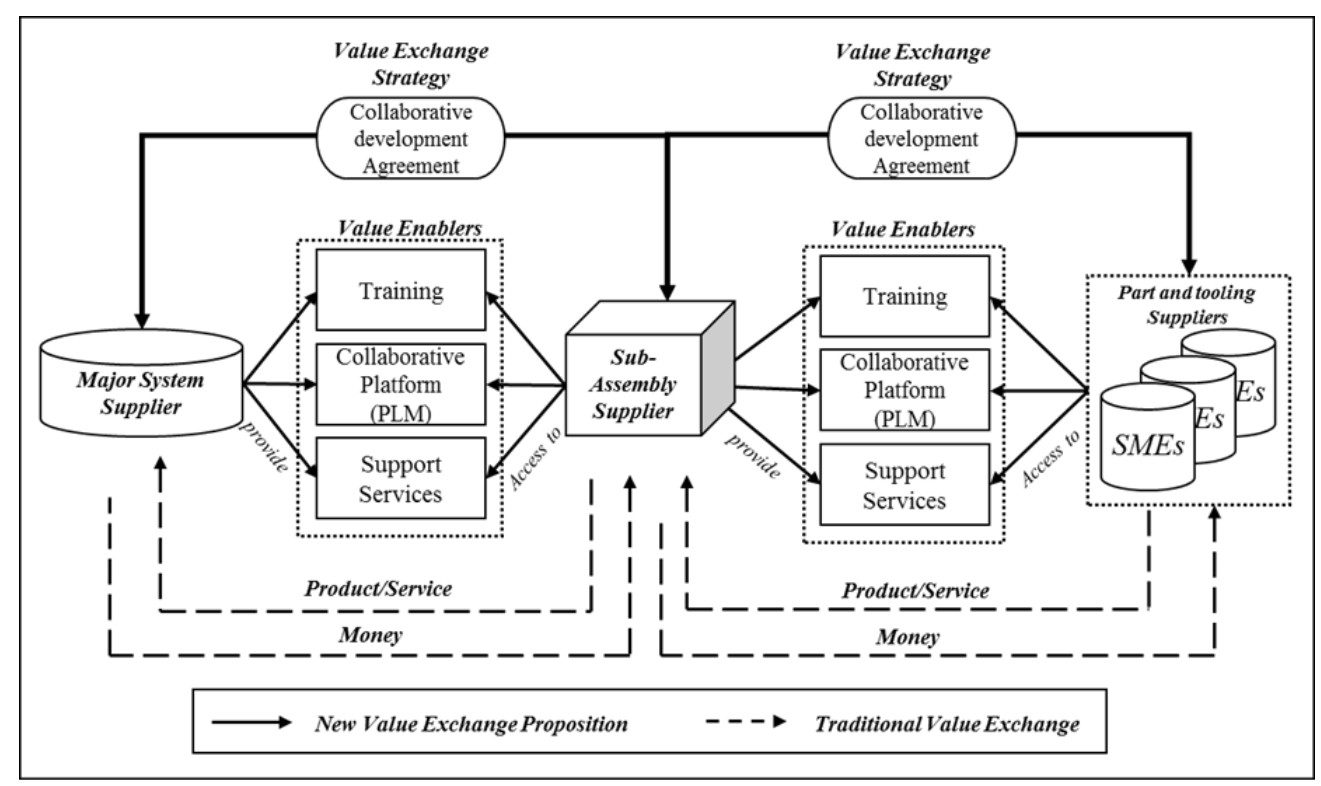

Figure 3. The New Business Model proposition

The concept of Value Exchange Strategies is realized by adopting a collaborative development model involving SMEs through an active participation within the projects. This approach is proposed as an extension of the already tested model of "risk-sharing" applied for some years, by the Program Leader with the Major System Suppliers (e.g. Boeing 787 Dreamliner, Falcon 7X Business Jet and Embraer 170/190 regional jet family).

Reasons behind the choice of a risk-sharing business model are essentially two: 1), the exorbitant costs of product manufacturing preclude the individual contractors (although giants like Boeing or Airbus) to wholly bear the full cost of the project; 2) the presence of high-tech components pushes manufacturers to create a team, geographically extended, in which each partner is a leader on the specific sub-parts of the product. Therefore, there is not a single prime contractor that provides a job order to major system suppliers but strategic agreements in which partners share the risks of development but benefit in terms of revenues, in relation to their share.

Starting from this consolidated approach, the idea, behind the networked business model proposal, is to extend this praxis even to lower levels of the production pyramid involving in such a way many SMEs operating in the territory. Obviously, it is unthinkable to automatically transfer the risk to SMEs because it would be impossible and counterproductive to load them with the financial risk. The first step, however, is to give responsibility and make them grow in a professional manner, involving them with the intension, in the long time, to revisit the concept of risk sharing and applying it to the third and fourth stages of the production pyramid.

This solution may allow SMEs to cling to international programs and thereby, to ensure stability, reducing the risks of failure and triggering a process of continuous innovation in the medium to long term.

Concretely, this solution acts on the value exchange process: the traditional model characterized by a "job order for money" changes in a system in which the higher level supplier still provides a contract but with different conditions. It namely involves SMEs through long-term agreements and pays not only in terms of money but also in terms of technological innovation.

For the second new component of the proposed model, "The Value Enablers", the cooperation strategy has to be supported by a suitable alignment process of the technological and organizational infrastructure to the standards required by the partnerships. Therefore, it becomes necessary the adoption of collaborative platforms that allow to:

- store, monitor and manage documents (texts, drawings, charts, etc.) and other information relating to products, both on paper and, especially, in electronic format;

- control the processes of creation and use of these documents;

- enable project teams to share information on products quickly and with guarantees of accuracy;

- integrate design techniques such as Computer Aided Design and Manufacturing (CAD/ CAM) with other enterprise systems (production, administration, etc.) across the entire company.

To satisfy these requirements, product lifecycle management systems (PLMs) have to be applied integrating the whole flow of information related to a product guaranteeing traceability and a long-term archiving of the data. The product lifecycle management (PLM) strategy involves the integration among individuals, organization and ICT systems to reach the best results $[47 ; 48]$.

The fundamental problem for SMEs is the access to these technologies in term of both financial commitment and management skills. This problem can be solved through multi-year contractual agreements in which large companies 
provide SMEs with the use of technology platforms, a program of training and support services. This model defines a new form of remuneration as an alternative to the money. In fact, while reducing revenue in the short term, it guarantees for SMEs a financial stability and a professional and technological growth over time.

\section{Conclusions}

Developing complex and innovative products requires an uninterrupted technological and organizational integration that can be achieved only through an increasing integration of firms with distinctive skills. The aerospace industry, characterized by product complexity and important financial size of development programs, has for long time tested techno-organizational models to streamline processes and reduce risks.

As pointed out above, Major Assembly Suppliers are increasingly oriented to constitute risk-sharing agreements, rather than simple supply contracts, in order to reduce the complexity of the supply chain and to ensure the full involvement of business partners in the customer value creation. This type of inter-organizational strategy is the prelude toward a model of specialized firm that follows specific trajectories of innovation and coevolves in a networked federated system supported by powerful and integrated IT technologies to manage among all the actors information and data on the products.

The proposed networked business model is conceived as an extension of what already is happening in business practice. In fact:

a. It is based on the concept of the extended collaboration among all nodes of a business network, regardless of size or type of activity carried out;

b. It aims to an active participation of each firm that preserves and maximizes the specific core Competences.

A successful Business Model requires a re-thinking of the inter-organizational structure that, extending the current emerging approach based on collaboration and risks sharing, can lead to a dynamic, flexible and value focused network of alliances.

Concluding, the paper proposes a networked Business Model based on the contribution of two new elements (i.e. value exchange strategy and value enablers) in the Value Unit. The new elements are new for the business model literature and find its validity in the exploration of the practices of the sampled aerospace companies providing an interesting field of discussion and orientation of business activities for the aerospace sector. With the paper results, the literature on Business Model is enlarged with these two new elements that can be used in further studies to test their wider application. In fact, generalization of the findings to other sectors or industry will require ad-hoc analysis.

\section{REFERENCES}

[1] Clark, K. B. and Fujimoto, T. (1991), Product Development Performance, Boston, MA: Harvard University Press.

[2] Smith, P. and Reinertsen, G. (1991), Developing Products in Half the Time, New York, Van Nostrand.

[3] Mabert, V. A., Muth, J.F. and Schmenner, R.W. (1992), "Collapsing New Product Development Times: Six Case Studies", Journal of Product Innovation Management, Vol. 9, No 3, pp. 200-212.

[4] Griffin, A. and Hauser, J. R.(1996), "Integrating Mechanisms for Marketing and R\&D", Journal of Product Innovation Management, Vol. 13, No. 3, pp. 191-215.

[5] Jagdev, H. S. and Browne, J., (1998), "The extended enterprise-a context for manufacturing", Production Planning \& Control: The Management of Operations, Vol. 9, No. 3, pp. $216-229$

[6] Anderson, J. and Narus, J. (1990), "A model of distributor firm and manufacturer firm working partnerships", Journal of Marketing, Vol. 54, pp. 42-58

[7] Ulrich, K.T. and Eppinger, S.D., (2008), Product Design and Development, McGraw Hill Education, Singapore

[8] Lawton-Smith, H., Dickson, K. and Lloyd-Smith, S. (1991), "There are two side to every story: innovation and collaboration within networks of small and large firms", Research Policy, Vol. 20, pp. 457-468

[9] Porter, K., Whittington, K. B. and Powel, W. W. (2005), "The institutional embeddedness of High-Tech Regions: Relational Foundations of the Boston Biotechnology Community", in Breschi, S., Malerba, F., Clusters, Networks and Innovation, Oxford Press

[10] kent

[11] Malerba, F. (1992), "Learning by firms and incremental technical change", Economic Journal, Vol. 102, pp. 845-9.

[12] Wilson, E. and Nielson, C.C. (2000), "Cooperation and Continuity in Strategic Business Relationships", Journal of Business-to-Business Marketing, Vol. 8, No.1, pp. 1-24

[13] Kueppers, G. (2002), "Complexity, self-organization and Innovation Networks: A new theoretical approach", in Pyka, A., Kueppers, G., Innovation Networks. Theory and Practice, Edward Elgar.

[14] Bamberg, G. and Coenenberg, A.G. (2002), Betriebswirtschaftliche Entscheidungslehre, 11th edition, VerlagVahlen, Munich.

[15] Timmers, P. (1999), Electronic Commerce, John Wiley \& Sons Inc., New York.

[16] Stewart, D. W. and Zhao, Q. (2000), "Internet marketing, business models and public policy", Journal of Public Policy and Marketing, Vol.19, pp. 287-296.

[17] Applegate, L. M. (2000), "E-business models: Making sense of the internet business landscape", in G. Dickson and G. DeSanctis , Information technology and the future enterprise: New models for managers, Englewood Cliffs, NJ: Prentice-Hall. 
[18] Weill, P. and Vitale, M. R. (2001), Place to space: Migrating to eBusiness Models. Harvard Business School Press, Boston.

[19] Morris, M., Schindehutte, M., and Allen, J. (2005), "The entrepreneur's business model: Toward a unified perspective", Journal of Business Research, Vol.58, pp. 726-35.

[20] Shafer, S. M., Smith, H. J. and Linder, J. (2005), "The power of business models", Business Horizons, Vol. 48, pp. 199-207.

[21] Dubosson-Torbay, M., Osterwalder, A. and Pigneur, Y. (2002), "E-business model design, classification, and measurements", Thunderbird International Business Review, Vol. 44, No. 1, pp. 5-23.

[22] Timmers, P. (1998), "Business Models for Electronic Markets”, EM - Electronic Markets, Vol. 8, No. 2, pp. 3-8.

[23] George, G. and Bock, A. (2009), The business model in practice and its implications for entrepreneurship research, available at http://ssrn.com/abstract $=1490251$ (accessed 9 June 2011).

[24] Osterwalder, A. (2004), "The business model ontology-A proposition in a design science approach", available at http://www.hec.unil.ch/aosterwa/PhD/2.pdf (accessed 2 June 2011)

[25] Osterwalder, A., Pigneur, Y. and Tucci, C.L., (2005), "Clarifying business models: Origins, present, and future of the concept", Communications of the Association for Information Systems, Vol. 16, No. 1, pp. 1-25.

[26] Amit, R. and Zott, C. (2001) "Value creation in e-business", Strategic Management Journal, Vol.22, pp. 493-520.

[27] Afuah, A. and Tucci, C.L. (2003), Internet Business Models and Strategies, 2nd edition, Boston, McGraw-Hill.

[28] Afuah, A. 2004, Business models: A strategic management approach, New York: Irwin/McGraw-Hill.

[29] Brousseau and Penard (2006)

[30] Seelos, C., and Mair, J. (2007), "Profitable business models and market creation in the context of deep poverty: A strategic view", Academy of Management Perspectives, Vol. 21, pp. 49-63.

[31] Osterwalder, A. and Pigneur, Y. (2010), Business Model Generation: A Handbook for Visionaries, Game Changers, and Challengers, John Wiley \& Sons, Inc.

[32] Wirtz, B.W. (2001), Electronic Business, Gabler, Wiesbaden.

[33] Yu, C.C. (2001), An Integrated Framework of Business Models for Guiding Electronic Commerce Applications and Case Studies. EC-Web2001, Lectures Notes in Computer Science, Vol. 2115, pp. 111-120.

[34] Conte, T. (2008), “A Framework for Business Models in
Business Value Networks", available at http://digbib.ubka.uni-karlsruhe.de/volltexte/1000009399 (accessed 3 June 2011).

[35] Chesbrough, H. (2006), Open Business Models: How to Thrive in the New Innovation Landscape, McGraw Hill Publications.

[36] Chesbrough, H. (2003)

[37] Ramaswamy, V. and Gouillart, F. (2010), The Power of Co-Creation: Build It with Them to Boost Growth, Productivity, and Profits, Free Press.

[38] Prahalad, C.K. and Ramaswamy, V. (2004), The Future of Competition: Co-Creating Unique Value with Customers, Harvard Business Review Press.

[39] Calantone, R., Garcia, R. and Dro" ge, C. (2003), "The Effects of Environmental Turbulence on New Product Development Strategy Planning", Journal of Product Innovation Management, Vol. 20, No. 2, pp. 90-103.

[40] Buganza, T., Dell'Era, C. and Verganti, R. (2004), "Exploring the Relationships between Product Development and Environmental Turbulence: The Case of Mobile TLC Services", paper presented at the 11th International Product DevelopmentManagement Conference, 20-22 June, Dublin, Ireland.

[41] Rikkiev, A., Seppänen, M., Mäkinen, S. J. (2012), Product convergence perspective on collaboration success factors, International Journal of Business and Systems Research, Vol. 6, No.1 pp. $36-58$.

[42] Gordijn et al., 2001

[43] Fensel, D. (2001), Ontologies: Silver Bullet for Knowledge Management and Electronic Commerce. Heidelberg, Springer-Verlag.

[44] Creswell, J. W. (2003), Research Design: Qualitative, Quantitative, and Mixed Methods Approaches, Sage Pubblications.

[45] Buratta, L., Sabbadini, L.L. and Fortunato E. (1989), Manuale di Tecniche d'Indagine, 2: il questionario: progettazione, redazione e verifica, ISTAT, Italy.

[46] Bryman, A. and Bell, E. (2007), Business Research Methods. Oxford Press.

[47] Alemanni, M., Grimaldi, A., Tornincasa, S. and Vezzetti, E. (2008), "Key performance indicators for PLM benefits evaluation: The Alcatel Alenia Space case study", Computers in Industry, Vol. 59, pp. 833-841

[48] Corallo, A., Latino, M.E., Lazoi, M., Lettera, S., Marra, M., and Verardi, S., 2013, Defining Product Lifecycle Management: a journey across features, definitions and concepts, ISRN Industrial Engineering, Vol. 2013. 